\title{
Environmental versus functional hypoxia/anoxia in sole Solea solea: the lactate paradox revisited
}

\author{
Josef Dalla Via $^{1, *}$, Guido van den Thillart ${ }^{2}$, Otello Cattani ${ }^{3}$, Paolo Cortesi ${ }^{3}$ \\ 'Department of Zoology and Limnology, Section of Ecophysiology, University of Innsbruck, Technikerstrasse 25, \\ A-6020 Innsbruck, Austria \\ ${ }^{2}$ Institute of Evolutionary and Ecological Sciences, University of Leiden, Gorlaeus Laboratoria, POB 9502, 2300 RA Leiden, \\ The Netherlands \\ ${ }^{3}$ Department of Biochemistry, University of Bologna, Via Tolara di Sopra 50, I-40064 Ozzano Emilia (Bologna), Italy
}

\begin{abstract}
The effects of hypoxia (12 and $6 \%$ air saturation), anoxia and forced exercise on intermediary metabolism were compared and the first $4 \mathrm{~h}$ of recovery after exhaustive exercise examined in common sole Solea solea. Intermediates of energy metabolism and lactate production were analyzed in white muscle, liver and blood. Rates of ATP production by anaerobic metabolism for the 4 different conditions were $52,150,1777$, and $6834 \mu \mathrm{mol} 100 \mathrm{~g}^{-1} \mathrm{~h}^{-1}$, respectively. Total anaerobic ATP yield was 625 , 1799,3074 , and $3132 \mu \mathrm{mol}$ ATP $100 \mathrm{~g}^{-1}$. Under hypoxia the energy consumption of the fish appeared to be depressed (i.e. below standard metabolic rate), while under anoxia the rate was at routine metabolic rate, and under forced exercise was twice the active metabolic rate. The muscle/blood lactate ratio after forced exercise was comparable to those found previously for other flatfish species; however, hypoxia exposure resulted in a completely inverse situation with blood lactate levels up to $20 \mathrm{mM}$, whereas anoxia resulted in an intermediate situation. The results challenge the present concept of lactate 'releasers' and 'non-releasers' describing the transfer of lactate from muscle tissue into the blood. It is concluded that the distinction between lacate 'releasers' and 'non-releasers' can no longer be applied on a species basis but must be related to type and intensity of the induced stress situation.
\end{abstract}

KEY WORDS: Intermediary metabolism - Metabolic depression - Forced exercise $\cdot$ Recovery $\cdot$ Lactate 'releaser' and 'non-releaser' - Flatfish

\section{INTRODUCTION}

Chronic hypoxic conditions are increasingly common in shallow coastal waters of the Northern Adriatic Sea. The typical summer conditions of high temperature, high nutrient load, calm sea, and high irradiation lead to algal blooms with up to $80 \%$ release of photosynthetically fixed carbon (Herndl et al. 1993). The coagulated matter and the marine snow form a sediment on the sea floor resulting in large areas with hypoxic or even transient anoxic conditions. The benthic common sole Solea solea is then trapped in hypoxic bottom water layers which may extend for up to $900 \mathrm{~km}^{2}$ (Rinaldi et al. 1993).

•E-mail: josef.dalla-via@uibk.ac.at
Under such environmental conditions escape behavior is pointless, especially since the locomotory activity of sole is restricted. Like other demersal fish without a functional swimbladder the sole shows an intermittent and shambling swimming behavior suitable only for travel over short distances and/or feeding activities (Lagardère et al. 1988). In addition the negative buoyancy of sole requires high lift-off energy for vertical displacement. Even at moderate swimming speeds of between 0.5 and 1.4 body lengths $\mathrm{s}^{-1}$ anaerobic energy metabolism in flatfish white muscle may amount to $15 \%$ of total energy expenditure (Duthie 1982). The distribution of lactic acid between muscle and blood in swimming and exercising flatfish is different from that in roundfish. Blood lactate concentrations rarely exceed $2 \mathrm{mM}$, despite elevated muscle lactate levels. This is true for plaice Pleuronectes platessa (Wardle 1978), 
flathead sole Hippoglossoides elassodon (Turner et al. 1983), starry flounder Platichthys stellatus (Milligan \& Wood 1987a, Milligan \& McDonald 1988), winter flounder Pseudopleuronectes americanus (Girard \& Milligan 1992) and other benthic fish like sea raven Hemitripterus americanus (Milligan \& Farrell 1986). A 'non-release' of lactic acid from flatfish muscle due to catecholamine stimulation was postulated by Wardle (1978).

In previous papers we presented evidence that anaerobic metabolism of sole is activated below $20 \%$ air saturation (Van den Thillart et al. 1994) and that at these oxygen levels routine metabolic rate is depressed by up to $48 \%$ (Dalla Via et al. 1994). Under environmental hypoxia this species also showed an inverse lactate distribution pattern compared to the above mentioned flatfish species (unexpectedly high blood lactate levels of up to $20 \mathrm{mM}$ and lower lactate concentrations in muscle of 5 to $10 \mathrm{mM}$; Dalla Via et al. 1994). The question was raised if this pattern was species-dependent, representing an exception within the flatfish, or if it was stress-dependent, since in our experiments hypoxia was used as an environmental stressor whereas the other flatfish species had been exposed to forced exercise. The aim of the present study was to compare functional and environmental hypoxia/anoxia as stressors and their impact on intermediary metabolism and end product accumulation.

\section{MATERIAL AND METHODS}

Animals. Sole Solea solea were obtained from local fishermen at the fishing harbour of Cesenatico (Italy) and kept at the Marine Biological Station (Centro di Ricerche Marine) from April to September at $20 \pm 1^{\circ} \mathrm{C}$ within a salinity range of 24 to $37 \mathrm{ppt}$. This long acclimation period appeared to be adequate for the fish to recover from trawling stress and to adapt to captive conditions in seawater aquaria with percolated sand beds acting as substrate and water filter. Seawater supply of the aquaria was maintained through a closed recirculating system with a water capacity of approximately $2 \mathrm{~m}^{3}$ and a weekly replacement of half the volume. Natural seawater was filtered through sand filters and the microbial load in the recirculated water was reduced by means of 2 UV-lamps. Animals were fed daily with live polychaetes (Nereis sp.) and remained in good health for several months in the aquaria (Van den Thillart \& Dalla Via 1993, Dalla Via et al. 1994, Van den Thillart et al. 1994). Immature sole with a mean weight of $62.3 \pm 20.5 \mathrm{~g}$ and a mean total length of $18.5 \pm 1.6 \mathrm{~cm}$ were used in the experiments. All experiments were carried out in September at $20^{\circ} \mathrm{C}$, salinity between 30 and $32 \mathrm{ppt}$, illumination set at the diurnal cycle for September. Prior to the experiments the fish were starved for $2 \mathrm{~d}$ and total starvation time up to sampling was kept constant for all experimental protocols.

Hypoxic/anoxic exposure. The data for the $12 \mathrm{~h}$ hypoxic exposure to 12 and $6 \%$ saturation are taken from an earlier paper (Dalla Via et al. 1994) and presented here in graphs and tables for comparative purposes. Comparisons are possible since the fish derive from the same batch, were kept under identical acclimation conditions and analysed with the same methods (Dalla Via et al. 1994, Van den Thillart et al. 1994). Anoxic exposure of sole was carried out in a constanttemperature $\left(20^{\circ} \mathrm{C}\right) 1501$ glass tank. Between 4 and 6 specimens were placed in the chamber and acclimatized for $48 \mathrm{~h} . P_{\mathrm{O}_{2}}$ was lowered to $5 \%$ air saturation within about $2 \mathrm{~h}$, then $\mathrm{O}_{2}$ was driven off completely and the behavior of the fish observed and recorded at intervals of 5 or $10 \mathrm{~min}$. When a fish no longer reacted to external stimuli, it was removed from the chamber and tissues were immediately sampled.

Forced exercise and recovery. The experiments on forced exercise and recovery were carried out in the same setup as the anoxia exposures. Individual fish were transferred from the normoxic conditions at $20^{\circ} \mathrm{C}$ to the experimental chamber and forced exercise was induced in the acclimatized fish by mechanically provoking escape behavior until exhaustion. Exhaustion was difficult to determine since sole lack a functional swimbladder and are negatively buoyant. Non-swimming individuals always sink to the bottom, where they remain motionless. In our case we defined exhaustion as when the sole failed to show coordinated and directed swimming behavior after lifting it by hand into the water column. When exhausted, fish were immediately removed from the chamber and tissues were sampled. For recovery experiments, individuals remained in the chamber for $15,30,60$, and $240 \mathrm{~min}$ after exhaustion and were sampled at these times. These fish were anaesthetized with MS222 (3-aminobenzoic-acid ethyl-ester methanesulfonate salt, Sigma, St. Louis, USA) to avoid the induction of handling and sampling stress. MS222 was added to the aquaria $10 \mathrm{~min}$ before sampling to a final concentration of $85 \mathrm{ppm}$ in the water.

Tissue sampling, metabolite extraction, and analysis were described in detail by Dalla Via et al. (1994). From anaestethized fish a tissue block of approximately $20 \times 20 \times 2 \mathrm{~mm}$ of the epaxial white muscle was freeze-clamped with precooled aluminum tongs $\left(-196^{\circ} \mathrm{C}\right)$. Blood samples were obtained from the caudal artery by severing the caudal fin. Liver was collected after dissection and freeze-clamped. The whole sampling procedure lasted between 60 and $90 \mathrm{~s}$ for one fish, freeze-clamping muscle tissue first (within 5 to 
$10 \mathrm{~s})$, sampling blood afterwards and finally collecting the liver tissue. Blood samples were immediately analyzed whereas freeze-clamped muscle and liver samples were stored in liquid nitrogen until analysis.

Blood samples were injected into $0.5 \mathrm{ml}$ ice-cold $6 \%$ perchloric acid (PCA) with $4 \mathrm{mM} \mathrm{NaF}$ and $4 \mathrm{mM}$ EDTA, homogenized with a sonicator (Soniprep 150HSE Scientific Instrumentations) for 1 to $2 \mathrm{~min}$ and centrifuged at $15000 \times \mathrm{g}$ for $20 \mathrm{~min}$ in a cooled centrifuge (Sigma 220). The $\mathrm{pH}$ of the supernatant was adjusted to between 6 and 7 with $2 \mathrm{M} \mathrm{K}_{2} \mathrm{CO}_{3}$ in $100 \mathrm{mM} \mathrm{K}_{2} \mathrm{HPO}_{4}$. Samples were kept on ice for $30 \mathrm{~min}$, then centrifuged for $20 \mathrm{~min}$ at $15000 \times \mathrm{g}$, and used immediately for metabolite analysis. Adenosine-5'triphosphate (ATP), glucose-6-phosphate (G6P), and glucose-1-phosphate (G1P) in blood extracts are intraerythrocytic metabolites so their concentration must be related to the number of blood cells. Since erythrocyte volume increases under hypoxia (Nikinmaa 1986), hematocrit values increase without relation to the number of erythrocytes. Thus we chose to take the blood sediment after homogenization and the first centrifugation step as a reference, also in view of the difficulties in obtaining hematocrit samples from all specimens. The sediment was dried at $60^{\circ} \mathrm{C}$ and the dry weight determined for each blood sample.

The freeze-clamped muscle slice was weighed and crushed in a stainless steel beaker under liquid nitrogen. Skin layers were removed by striking the tissue slice with an iron pestle, muscle fibres being crushed and skin layers remaining intact. The mixture of liquid nitrogen and muscle fibres was transferred to a precooled mortar mill (Retsch RMO, Germany) where the tissue was pulverized under liquid nitrogen after addition of 5 volumes of extraction medium consisting of $15 \%$ PCA and 5\% ortho-phosphoric acid (Dalla Via \& Lackner 1991, Dalla Via et al. 1994). The obtained powder was thawed in an alcohol bath at -8 to $-10^{\circ} \mathrm{C}$ to avoid degradation of phosphorylated compounds, well mixed and left on ice for $30 \mathrm{~min}$ before centrifugation at $26600 \times \mathrm{g}$ for $20 \mathrm{~min}$ (refrigerated Sorvall $\mathrm{RC} 2-\mathrm{B}, \mathrm{SS} 34,4^{\circ} \mathrm{C}$ ). The supernatant was neutralized with $5 \mathrm{M} \mathrm{K}_{2} \mathrm{CO}_{3}$, centrifuged again after a precipitation time of $30 \mathrm{~min}$, and its volume determined by weight and corrected for density difference. The obtained supernatant was immediately used for enzymatic determination of metabolites.

The freeze-clamped liver was treated in an analogous way starting by pulverizing it under liquid nitrogen in the mortar mill. Due to the low biomass of sole liver $(0.6 \%$ of total body weight) the small supernatant volume derived from the extraction did not allow analysis of the same set of metabolites as in muscle tissue.

Metabolites were measured enzymatically by determining the changes in absorbance of nicotinamide coenzyme at $340 \mathrm{~nm}$ as described in Bergmeyer (1984, $1985 a, b)$ and Dalla Via et al. (1989). Lactic acid concentration in blood was determined with the L-lactatekit (Boehringer no. 139084, Mannheim).

Calculation of total anaerobic energy production. Determination of the key metabolites in energy metabolism allows estimation of total anaerobic energy production under the given conditions. Calculations were done according to Dalla Via et al. (1994) based on concentration changes in phosphocreatine (muscle only), lactate and ATP in muscle, liver and blood. Phosphocreatine is equivalent to 1 ATP, and lactate, originating mainly from glycogen, is equivalent to $1.5 \mathrm{ATP}$. In sole a relative tissue mass for muscle $(65 \%)$, blood + extracellular volume $(4+4=8 \%)$, liver $(0.63 \%)$, and the rest of metabolically active biomass (15\%) is assumed, with a presumed metabolic activity of the latter being similar to that in liver (Dalla Via et al. 1994). Values were calculated for each individual and expressed in $\mu \mathrm{mol}$ ATP $100 \mathrm{~g}^{-1} \mathrm{~h}^{-1}$. For blood metabolites $1 \mathrm{ml}$ blood was assumed to be $1 \mathrm{~g}$, and blood ATP levels based on dry sediment weight were corrected for volume.

Statistics. Statistical analysis was performed by CSS (Complete Statistical Systems, Statsoft Inc. release 3.1) and STATISTICA for Windows (Statsoft Inc. release $4.5,1993)$. Different treatments were compared to control conditions ( $=$ normoxia at rest and $20^{\circ} \mathrm{C}$ ) using the non-parametric Mann-Whitney $U$-test, where significance at $\mathrm{p}<0.05$ and $\mathrm{p}<0.01$ is indicated in graphs and tables by ${ }^{*}$ and $\cdots$, respectively.

\section{RESULTS}

Lactate concentration increased significantly in all tissues and under all treatments as compared to controls (Fig. 1). In muscle, anoxic conditions and exhaustion led to an approximately 16 -fold increase in lactate concentration. In liver and blood the highest lactate concentrations were found after $12 \mathrm{~h}$ of exposure to $6 \%$ air saturation, attaining from 16 to 75 times higher values than the controls. The ratio between muscle and blood lactate was 0.72 (at $12 \%$ air saturation) and 0.49 (at $6 \%$ air saturation) after $12 \mathrm{~h}$ of hypoxia, 2.27 under anoxic conditions and 4.57 after exhaustion. Within a recovery period of $4 \mathrm{~h}$ lactate concentrations did not reach normoxic values in any of the investigated tissues, remaining at 10-, 11 - and 30-fold control values in muscle, liver and blood.

Glucose concentration in muscle was significantly higher under both environmental and functional hypoxia (Fig. 2). Under certain hypoxic and anoxic conditions (e.g. anoxia in liver, hypoxia in blood) glucose concentrations in liver and blood were so sharply differentiated that it proved feasible to distinguish 


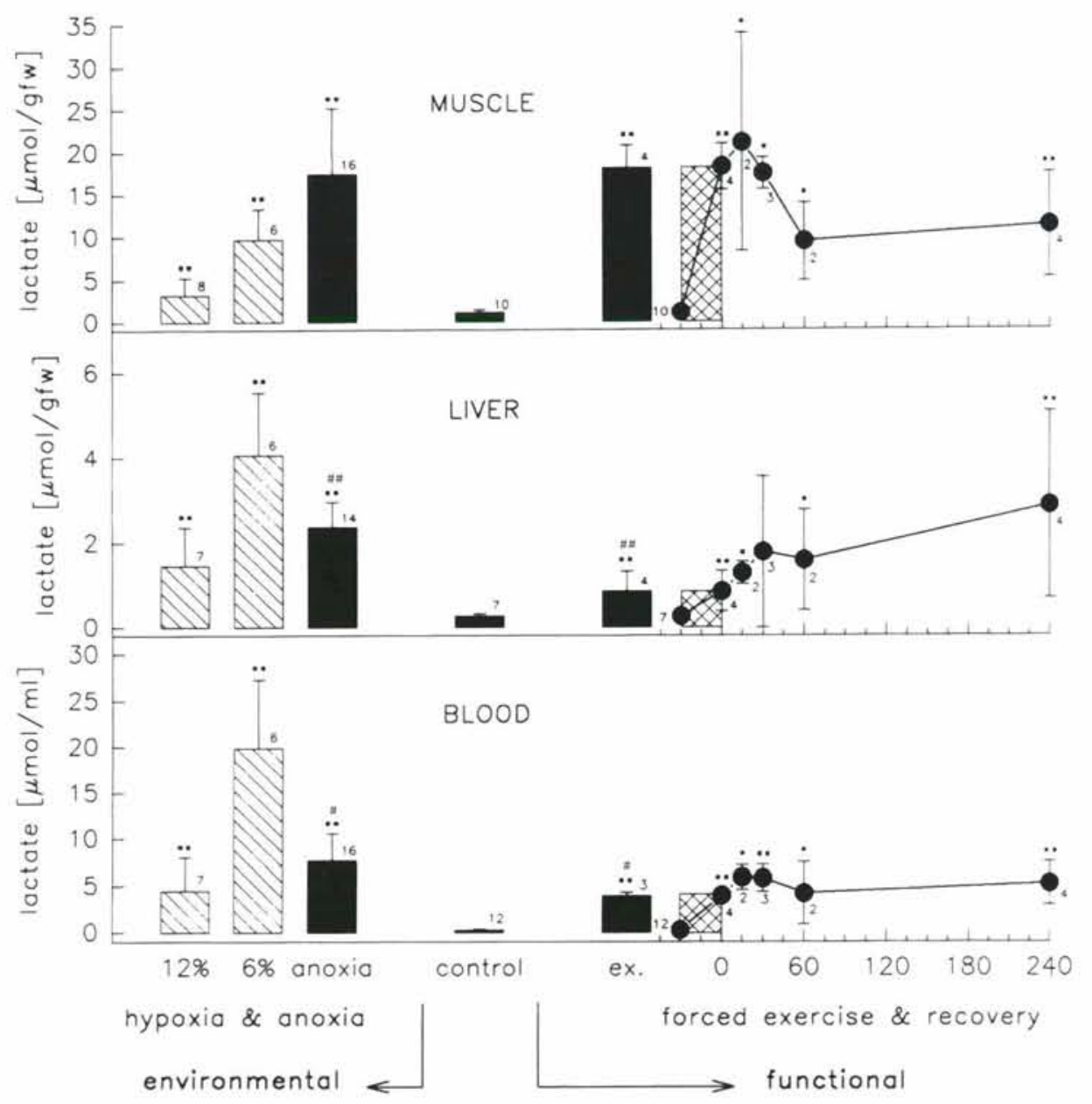

Fig. 1. Solea solea. Plot of lactate concentrations in muscle, liver and blood. Concentrations under control conditions (= normoxia, rest, $20^{\circ} \mathrm{C}$ ) are given in the centre to allow comparison to lactate concentrations under environmental (left) and functional hypoxia (right). Lactate concentrations under control conditions, anoxia and exhaustion are presented as solid bars. Concentrations after $12 \mathrm{~h}$ of hypoxic exposure to 12 and $6 \%$ air saturation are presented as hatched bars. The cross hatched bar on the right indicates the concentration change from control to exhaustion (-). Recovery time starts at zero at the end of forced locomotion (ex = exhaustion), and metabolite concentrations were determined at 15, 30, 60, and $240 \mathrm{~min}$. Metabolite concentrations are

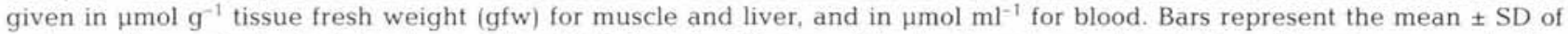
$\mathrm{n}$ observations as indicated close to each bar. Statistical significance of the treatment against control conditions is represented by ${ }^{\circ} \mathrm{p}<0.05 ;{ }^{\prime} \mathrm{p}<0.01$. Significant differences between anoxia and exhaustion are indicated by "p $<0.05 ; " \mathrm{p}<0.01$. All tests were carried out with the Mann-Whitney $U$-test

2 different concentration ranges within one treatment: some fish remained at control level, the rest forming a significantly different hyperglycaemic group. During exhaustion glucose values increased in all tissues, rising during recovery (muscle) or remaining at approximately the same level (blood). Only in liver did glucose concentrations reach resting values within 1 to $4 \mathrm{~h}$ of recovery,

Changes of the other metabolites during treatments are presented in Figs. $3 \& 4$ and Tables 1 \& 2, in a way that allows direct comparison among treatments and with the controls. The data for 12 and $6 \%$ hypoxia are taken from a previous paper for comparison (Dalla Via et al. 1994).

\section{DISCUSSION}

\section{Anaerobic metabolism: hypoxia, anoxia and anaerobic capacity}

The sole, a benthic living fish, has to cope with frequent hypoxic and sometimes anoxic conditions. In our experiments activation of anaerobic metabolism was induced by (1) severe hypoxia (12 h at 12 and $6 \%$ air saturation), (2) anoxic exposure (1.73 $\pm 0.55 \mathrm{~h})$, and (3) exhaustive exercise (vigorously chasing the fish until exhaustion for $27.5 \pm 7.6 \mathrm{~min}$ ).

Exposed to moderate hypoxia ( 80 to $20 \%$ air saturation), sole reduce their routine locomotor activity (Van 


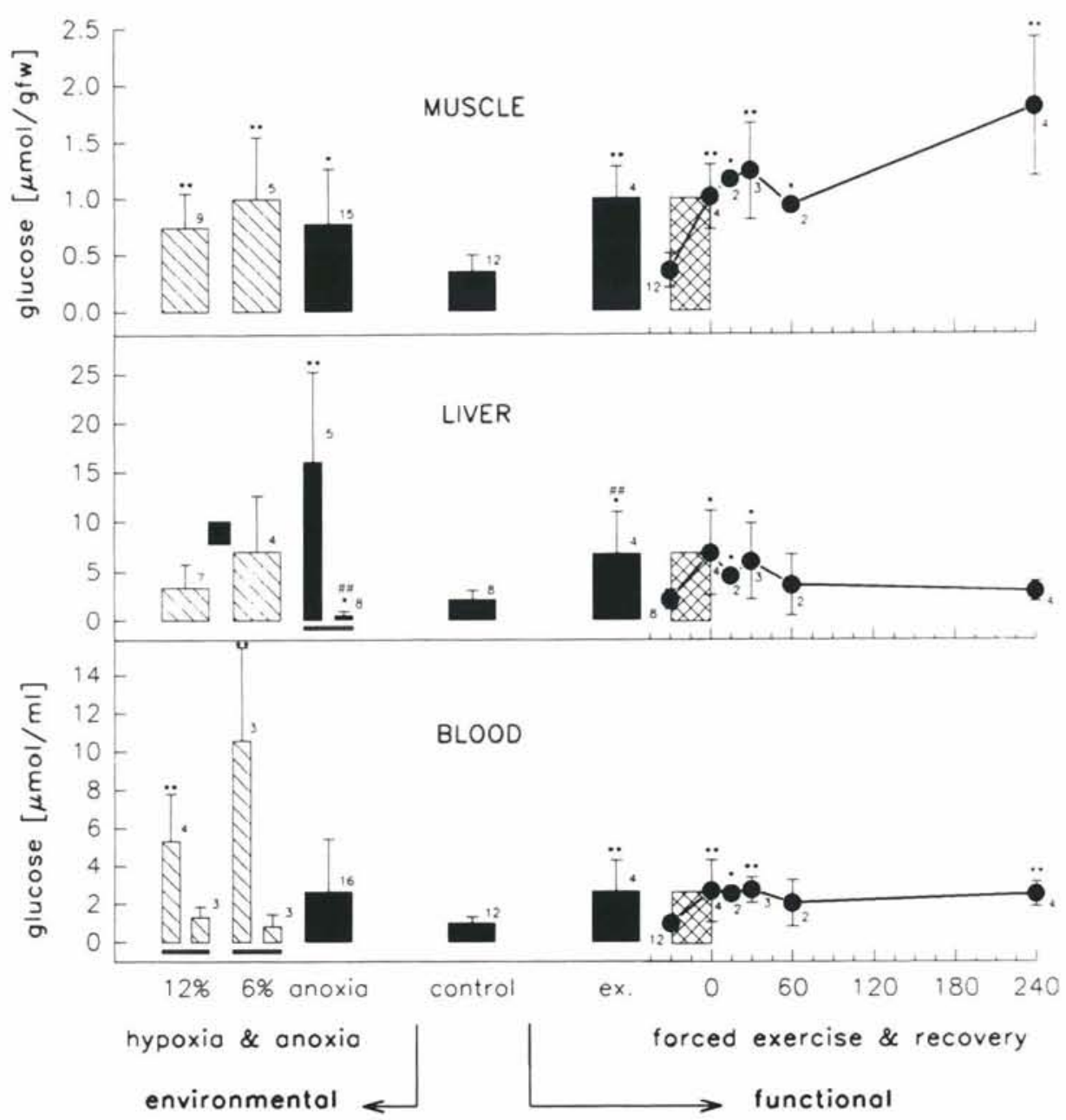

Fig. 2. Solea solea. Glucose concentrations in muscle, liver and blood of fish under environmental and functional hypoxia/anoxia (for details see legend to Fig. 1)

den Thillart et al. 1994). The fish start panicking at $5 \%$ air saturation or lower, attempting a last avoidance reaction by swimming up in the water column with burst swimming movements which become uncoordinated below $3 \%$ air saturation, the fish losing their balance and sinking to the bottom.

We know from previous papers (Dalla Via et al. 1994, Van den Thillart et al. 1994) that in sole anaerobic metabolism is activated below $20 \%$ air saturation and that total energy turnover is depressed by 27 and $48 \%$ at 12 and $6 \%$ air saturation, respectively. The capacity for metabolic depression in the white muscle is a significant adaptation to hypoxia. In terms of reducing the demand for oxygen this strategy is more effective than the induction of anaerobic metabolism, which amounts to only 6 and $18 \%$ of the normoxic standard metabolic rate (SMR) at the 2 hypoxic levels indicated (Dalla Via et al. 1994).

Lactate concentrations in muscle are lower under hypoxia than under anoxia or after exhaustive exercise
(Fig, 1). In consequence, ATP levels in muscle after hypoxic exposure are practically unchanged control levels (Fig. 3) suggesting a non-activated state of phosphofructokinase (PFK) and low glycolytic flux at the end of the hypoxic exposure when the samples were taken. Phosphocreatine, which drives the regeneration of ATP, decreased by only $44 \%$ (at $6 \%$ air saturation; Fig. 4). Furthermore, the significant fall in blood [ATP] (Fig. 3) and the increase in blood sediment during hypoxia (Fig. 5) indicate a higher hemoglobin-oxygen affinity and an increase of oxygen-carrying capacity (discussed in Dalla Via et al. 1994).

Anoxic exposure leads to almost complete depletion of phosphocreatine in muscle (Fig. 4) and to a reduction of ATP by $49 \%$ (Fig. 3). High muscle lactate concentrations (17.4 $\left.\mu \mathrm{mol} \mathrm{g}^{-1}\right)$ and anaerobic energy production of $1777 \mu$ mol ATP $100 \mathrm{~g}^{-1} \mathrm{~h}^{-1}$ (Table 3) are characteristic for the high glycolytic flux under anoxia. Lactate accumulation in sole after anoxia amounted to $1226 \mu \mathrm{mol} 100 \mathrm{~g}^{-1}$ fish (muscle $65 \%$, liver $0.63 \%$, blood 


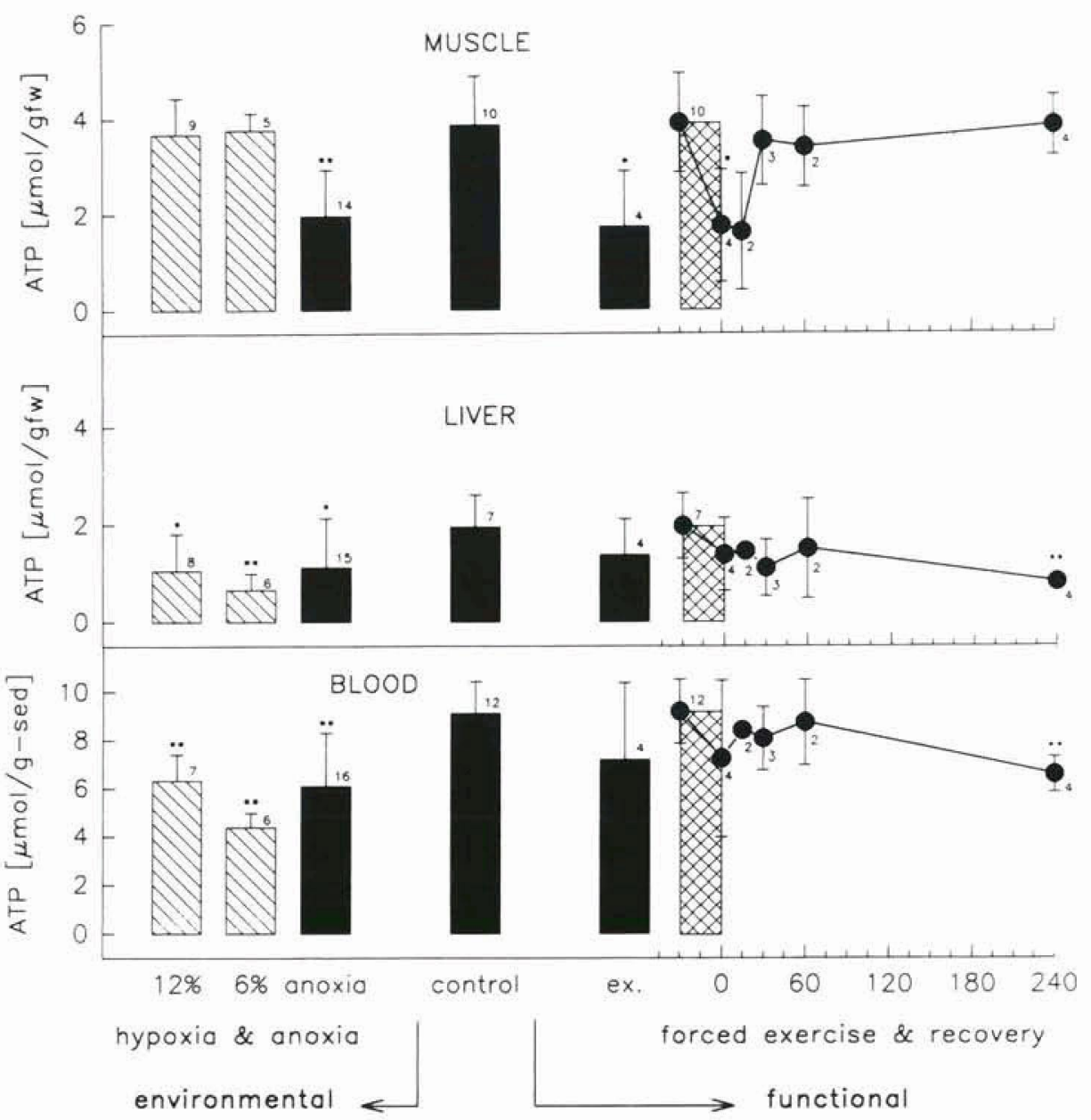

Fig. 3. Solea solea. ATP concentrations in muscle, liver and blood of fish under environmental and functional hypoxia/anoxia (for details see legend to Fig. 1). Concentrations in blood are given $\mathrm{g}^{-1}$ dry blood sediment ( $\mathrm{g}$-sed) as a reference for blood cell mass

$8 \%$, rest active biomass $15 \%$ ). A similar value of $1214 \mu \mathrm{mol} 100 \mathrm{~g}^{-1}$ fish can be calculated for exhaustive exercise. If we assume that the lactate formed is due to glycogenolysis, total glycogen levels in sole must be at least around $600 \mu \mathrm{mol}$ glycosyl units $100 \mathrm{~g}^{-1}$ fish. Glycogen is the major storage form of glucose and found mainly in liver and muscle cells. Since total liver mass is less than $1 \%$ in sole, liver glycogen may not play a prominent role as an energy store. Unfortunately we were not able to measure glycogen in muscle and liver, but comparing the calculated $600 \mu \mathrm{mol}$ glycosyl units $100 \mathrm{~g}^{-1}$ fish with literature values for flat-

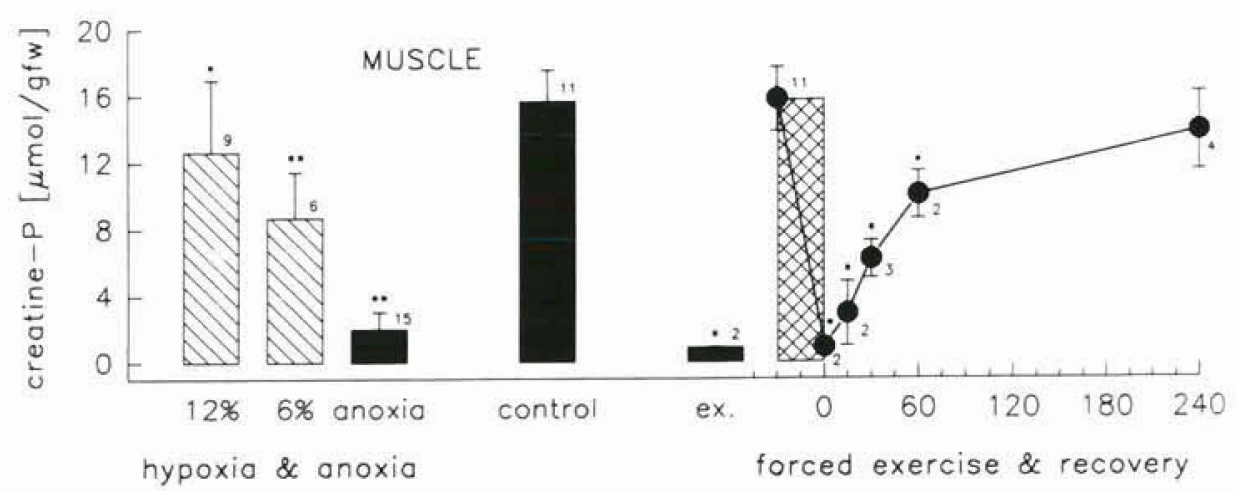

Fig. 4. Solea solea. Phosphocreatine levels in muscle of fish under environmental and functional hypoxia/anoxia (for details see legend to Fig. 1) 
Table 1. Solea solea. Metabolite profiles in muscle tissue after $12 \mathrm{~h}$ of severe hypoxia (12 and $6 \%$ air saturation), $1.7 \mathrm{~h}$ of anoxia, $27.5 \mathrm{~min}$ of exhaustive exercise and during the following $4 \mathrm{~h}$ of recovery. Metabolite values are given in $\mu \mathrm{mol} \mathrm{g}^{-1} \mathrm{fresh}$ weight tissue, as mean $\pm \mathrm{SD}$ with number of analysed samples given in brackets. Values are compared to normoxic and resting controls, significant differences being marked with ${ }^{*} p<0.05$ and $* p<0.01$

\begin{tabular}{|c|c|c|c|c|c|c|c|c|c|}
\hline & $12 \%$ & $6 \%$ & Anoxia & Control & Exhaust. & $15 \mathrm{~min}$ & $30 \mathrm{~min}$ & $60 \mathrm{~min}$ & $240 \mathrm{~min}$ \\
\hline G1P & $\begin{array}{r}0.087 \cdot \cdot \\
\pm 0.030(8)\end{array}$ & $\begin{array}{r}0.111 * \\
\pm 0.054(6)\end{array}$ & $\begin{array}{c}0.056 \\
\pm 0.038(15)\end{array}$ & $\begin{aligned} & 0.035 \\
\pm & 0.011(8)\end{aligned}$ & $\begin{array}{r}0.132 \cdot \cdot \\
\pm 0.088(4)\end{array}$ & $\begin{array}{c}0.083^{\circ} \\
\pm 0.034(2)\end{array}$ & $\begin{array}{c}0.065 \\
\pm 0.036(3)\end{array}$ & $\begin{array}{c}0.060 \\
\pm 0.035(2)\end{array}$ & $\begin{array}{c}0.113^{\circ} \\
\pm 0.040(4)\end{array}$ \\
\hline G6P & $\begin{array}{r}0.946 * \\
\pm 0.407(9)\end{array}$ & $\begin{aligned} & 1.943 * \\
\pm & 0.516(6)\end{aligned}$ & $\begin{array}{c}0.914 \\
\pm 0.745(16)\end{array}$ & $\begin{array}{c}0.242 \\
\pm 0.092(12)\end{array}$ & $\begin{array}{c}1.012 \\
\pm 0.804(4)\end{array}$ & $\begin{array}{c}1.366^{\circ} \\
\pm 0.871(2)\end{array}$ & $\begin{array}{c}1.080^{\circ} \\
\pm 0.765(3)\end{array}$ & $\begin{array}{c}0.996^{\circ} \\
\pm 0.210(2)\end{array}$ & $\begin{array}{r}1.976 \% \\
\pm 1.062(4)\end{array}$ \\
\hline F6P & $\begin{array}{r}0.185 * \\
\pm 0.098(9)\end{array}$ & $\begin{array}{c}0.355 * \\
\pm 0.131(6)\end{array}$ & $\begin{array}{c}0.199 \\
\pm 0.164(16)\end{array}$ & $\begin{array}{c}0.062 \\
\pm 0.022(12)\end{array}$ & $\begin{array}{c}0.199^{\circ} \\
\pm 0.154(4)\end{array}$ & $\begin{array}{c}0.289^{\circ} \\
\pm 0.182(2)\end{array}$ & $\begin{array}{c}0.208^{\circ} \\
\pm 0.192(3)\end{array}$ & $\begin{array}{c}0.223^{\circ} \\
\pm 0.056(2)\end{array}$ & $\begin{array}{r}0.464 \cdots \\
\pm 0.236(4)\end{array}$ \\
\hline Fructose & $\begin{array}{c}0.054 \\
\pm 0.034(8)\end{array}$ & $\begin{array}{c}0.116 \\
\pm 0.060(4)\end{array}$ & $\begin{array}{c}0.078 \\
\pm 0.074(11)\end{array}$ & $\begin{array}{c}0.039 \\
\pm 0.038(6)\end{array}$ & $\begin{array}{c}0.090 \\
\pm 0.089(3)\end{array}$ & $\begin{array}{c}0.075 \\
\pm 0.001(2)\end{array}$ & $\begin{array}{c}0.157^{\circ} \\
\pm 0.045(3)\end{array}$ & $\begin{array}{c}0.161^{\circ} \\
\pm 0.006(2)\end{array}$ & $\begin{array}{c}0.308^{\circ} \\
\pm 0.125(2)\end{array}$ \\
\hline Pyruvate & $\begin{array}{c}0.043^{\circ} \\
\pm 0.019(9)\end{array}$ & $\begin{array}{c}0.036^{\circ} \\
\pm 0.016(6)\end{array}$ & $\begin{array}{c}0.202 \cdot . \\
\pm 0.120(16)\end{array}$ & $\begin{array}{c}0.021 \\
\pm 0.008(7)\end{array}$ & $\begin{array}{r}0.324 \cdot \cdot \\
\pm 0.074(4)\end{array}$ & $\begin{array}{c}0.392^{\circ} \\
\pm 0.126(2)\end{array}$ & $\begin{array}{c}0.223^{\circ} \\
\pm 0.125(3)\end{array}$ & $\begin{array}{c}0.216^{\circ} \\
\pm 0.005(2)\end{array}$ & $\begin{array}{r}0.260^{*} \\
\pm 0.188(4)\end{array}$ \\
\hline Malate & $\begin{array}{c}0.063 \\
\pm 0.029(9)\end{array}$ & $\begin{array}{c}0.100^{*} \\
\pm 0.047(6)\end{array}$ & $\begin{array}{c}0.150 * \\
\pm 0.113(16)\end{array}$ & $\begin{array}{c}0.051 \\
\pm 0.013(11)\end{array}$ & $\begin{array}{r}0.131 \cdots \\
\pm 0.041(4)\end{array}$ & $\begin{array}{c}0.179^{\circ} \\
\pm 0.050(2)\end{array}$ & $\begin{array}{c}0.168^{\circ} \\
\pm 0.078(3)\end{array}$ & $\begin{array}{c}0.228^{\circ} \\
\pm 0.111(2)\end{array}$ & $\begin{array}{r}0.177 \cdot \cdot \\
\pm 0.073(4)\end{array}$ \\
\hline$\alpha$-ketoglutarate & $\begin{array}{c}0.014 \\
\pm 0.007(8)\end{array}$ & $\begin{array}{c}0.007 \\
\pm 0.004(5)\end{array}$ & $\begin{array}{c}0.010 \\
\pm 0.008(13)\end{array}$ & $\begin{array}{c}0.012 \\
\pm 0.007(10)\end{array}$ & $\begin{array}{c}0.024 \\
\pm 0.023(2)\end{array}$ & $\begin{array}{c}0.010 \\
\pm 0.007(2)\end{array}$ & $\begin{array}{c}0.014 \\
\pm 0.013(3)\end{array}$ & $\begin{array}{c}0.021 \\
\pm 0.001(2)\end{array}$ & $\begin{array}{c}0.029^{\circ} \\
\pm 0.013(4)\end{array}$ \\
\hline $\begin{array}{l}\text { Glycerol-3- } \\
\text { phosphate }\end{array}$ & $\begin{array}{c}0.033 \\
\pm 0.037(8)\end{array}$ & $\begin{array}{c}0.105 \\
\pm 0.098(6)\end{array}$ & $\begin{array}{c}0.257^{*} \\
\pm 0.170(16)\end{array}$ & $\begin{array}{c}0.019 \\
\pm 0.027(8)\end{array}$ & $\begin{array}{c}0.309 \\
\pm 0.253(4)\end{array}$ & $\begin{array}{c}0.273^{\circ} \\
\pm 0.221(2)\end{array}$ & $\begin{array}{c}0.251 \\
\pm 0.213(3)\end{array}$ & $\begin{array}{c}0.180 \\
\pm 0.188(2)\end{array}$ & $\begin{array}{c}0.230^{\circ} \\
\pm 0.289(4)\end{array}$ \\
\hline $\mathrm{NH}_{4}{ }^{\circ}$ & $\begin{array}{c}0.224 \\
\pm 0.184(7)\end{array}$ & $\begin{array}{c}0.202 \\
\pm 0.167(4)\end{array}$ & $\begin{array}{c}1.434 \cdot \cdot \\
\pm 0.638(14)\end{array}$ & $\begin{array}{c}0.301 \\
\pm 0.233(10)\end{array}$ & $\begin{array}{r}1.299 \cdot \\
\pm 0.367(4)\end{array}$ & $\begin{array}{c}1.441^{\circ} \\
\pm 0.490(2)\end{array}$ & $\begin{array}{c}0.926 \\
\pm 0.119(2)\end{array}$ & $\begin{array}{c}0.889 \\
\pm 0.272(2)\end{array}$ & $\begin{array}{c}0.625^{\circ} \\
\pm 0.342(4)\end{array}$ \\
\hline
\end{tabular}

fish which range between 300 and $750 \mu \mathrm{mol} 100 \mathrm{~g}^{-1}$ fish (Jørgensen \& Mustafa 1980, Girard \& Milligan 1992), almost complete depletion of glycogen stores may be assumed.

Fuel depletion is also suggested by the fact that for both anoxia and exhaustive exercise the total anaerobic energy production in sole was limited to approximately $3100 \mu \mathrm{mol}$ ATP $100 \mathrm{~g}^{-1}$ (Table 3 ). Since exhaustion after exercise and failure to react to external stimuli after anoxia occur at different times, total anaerobic energy production of each individual was determined considering individual lengths of treatment (for details see 'Material and Methods', and Dalla Via et al. 1994). The data assembled in Table 3 show that the rate of anaerobic ATP production was almost 4 times higher under forced exercise than under anoxia, and 45 to 130 times higher than under severe hypoxia. Despite different rates of anaerobic energy metabolism under anoxia and exhaustive exercise, total anaerobic capacity reached approximately the same value, i.e. $3.1 \mathrm{mmol}$ ATP $100 \mathrm{~g}^{-1}$. This suggests that the total anaerobic capacity is fuel (glycogen) rather than rate limited.

At the end of anoxic exposure sole present a similar metabolic pattern as under exhaustive exercise, i.e. significantly lower concentrations of phosphocreatine and ATP as well as significantly higher concentrations of glucose, pyruvate, malate, and ammonia in muscle. Significant differences between the 2 treatments $(\mathrm{p}<$ 0.05 ) were found with respect to lactate, glucose and
Fig. 5. Solea solea. Blood sediment expressed in \% dry blood sediment $\mathrm{ml}^{-1}$ blood $\left(\mathrm{g} \times 100 \mathrm{ml}^{-1}\right)$. Blood sediment obtained after the first centrifugation (see 'Material and methods') is an indicator of cell biomass in the blood. For details see legend to Fig. 1

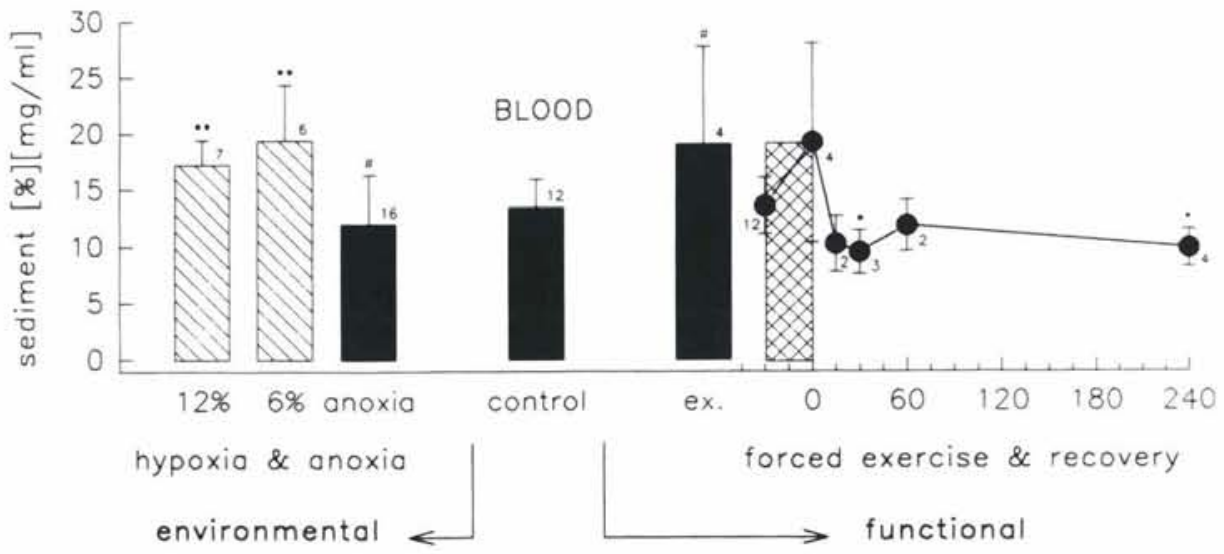


Table 2. Solea solea. Metabolite profiles in liver and blood of fish after $12 \mathrm{~h}$ of hypoxia (12 and $6 \%$ air saturation), $1.7 \mathrm{~h}$ of anoxia, $27.5 \mathrm{~min}$ of exhaustive exercise and during the following $4 \mathrm{~h}$ of recovery. Liver metabolite values are given in $\mu$ mol $\mathrm{g}^{-1} \mathrm{fresh}$ weight tissue; blood metabolites are given in $\mu \mathrm{mol} \mathrm{g}^{-1}$ dry blood sediment (as a reference for blood cell mass). All values given as mean $\pm \mathrm{SD}$ with number of analysed samples in brackets. Values are compared to normoxic and resting controls, significant differences being marked with $\cdot p<0.05$ and ${ }^{\prime} p<0.01$. Significant differences between anoxia and exhaustion are marked with "p $<0.05$ and $" \mathrm{p}<0.01$, nd: not determined

\begin{tabular}{|c|c|c|c|c|c|c|c|c|c|}
\hline & $12 \%$ & $6 \%$ & Anoxia & Control & Exhaust. & $15 \mathrm{~min}$ & $30 \mathrm{~min}$ & $60 \mathrm{~min}$ & $240 \mathrm{~min}$ \\
\hline \multicolumn{10}{|l|}{ Liver } \\
\hline G1P & $\begin{array}{c}0.046 \\
\pm 0.014(6)\end{array}$ & $\begin{array}{c}0.054 \\
\pm 0.026(6)\end{array}$ & $\begin{array}{c}0.068 \\
\pm 0.039(13)\end{array}$ & $\begin{array}{c}0.037 \\
\pm 0.014(7)\end{array}$ & $\begin{array}{c}0.047 \\
\pm 0.012(3)\end{array}$ & $\begin{array}{c}0.066 \\
\pm 0.029(2)\end{array}$ & $\begin{array}{c}0.082^{\circ} \\
\pm 0.021(3)\end{array}$ & $\begin{array}{c}0.050 \\
\pm 0.020(2)\end{array}$ & $\begin{array}{c}0.046 \\
\pm 0.024(4)\end{array}$ \\
\hline G6P & $\begin{array}{c}0.238 \\
\pm 0.168(7)\end{array}$ & $\begin{array}{c}0.549 \\
\pm 0.587(4)\end{array}$ & $\begin{array}{c}0.344 \\
\pm 0.255(15)\end{array}$ & $\begin{array}{c}0.314 \\
\pm 0.108(8)\end{array}$ & $\begin{array}{c}0.590 \\
\pm 0.331(3)\end{array}$ & $\begin{array}{c}0.573^{\circ} \\
\pm 0.055(2)\end{array}$ & $\begin{array}{c}0.585^{\circ} \\
\pm 0.150(3)\end{array}$ & $\begin{array}{c}0.536 \\
\pm 0.600(2)\end{array}$ & $\begin{array}{c}0.344 \\
\pm 0.249(4)\end{array}$ \\
\hline F6P & $\begin{array}{c}0.087 \\
\pm 0.043(6)\end{array}$ & $\begin{array}{c}0.038 \\
\pm 0.035(3)\end{array}$ & $\begin{array}{c}0.088 \\
\pm 0.066(14)\end{array}$ & $\begin{array}{c}0.067 \\
\pm 0.033(7)\end{array}$ & $\begin{array}{c}0.115 \\
\pm 0.061(4)\end{array}$ & $\begin{array}{c}0.116 \\
\pm 0.011(2)\end{array}$ & $\begin{array}{c}0.143 \\
\pm 0.024(3)\end{array}$ & $\begin{array}{c}0.127 \\
\pm 0.129(2)\end{array}$ & $\begin{array}{c}0.055 \\
\pm 0.058(4)\end{array}$ \\
\hline Fructose & $\begin{array}{c}0.017 \\
\pm 0.017(2)\end{array}$ & $\begin{array}{c}0.025 \\
\pm 0.019(3)\end{array}$ & $\begin{array}{c}0.027 \\
\pm 0.015(4)\end{array}$ & $\begin{array}{c}0.079 \\
\pm 0.078(2)\end{array}$ & nd & nd & $\begin{array}{c}0.032 \\
\pm 0.009(2)\end{array}$ & nd & $\begin{array}{c}0.075 \\
\pm 0.060(3)\end{array}$ \\
\hline Pyruvate & $\begin{array}{c}0.058 \\
\pm 0.044 \text { (5) }\end{array}$ & $\begin{array}{c}0.052 \\
\pm 0.037(3)\end{array}$ & $\begin{array}{c}0.038 \\
\pm 0.011(8)\end{array}$ & $\begin{array}{c}0.036 \\
\pm 0.037(4)\end{array}$ & $0.106(1)$ & $\begin{array}{c}0.044 \\
\pm 0.040(2)\end{array}$ & nd & nd & $\begin{array}{c}0.117 \\
\pm 0.152(3)\end{array}$ \\
\hline Malate & $\begin{array}{c}0.542 \\
\pm 0.264 \text { (7) }\end{array}$ & $\begin{array}{c}0.400 \\
\pm 0.208(6)\end{array}$ & $\begin{array}{c}0.665 * \\
\pm 0.229(15)\end{array}$ & $\begin{array}{c}0.329 \\
\pm 0.248(6)\end{array}$ & $\begin{array}{c}0.834^{\circ} \\
\pm 0.447(4)\end{array}$ & $\begin{array}{c}0.913 \\
\pm 0.448(2)\end{array}$ & $\begin{array}{c}0.962^{\circ} \\
\pm 0.496(3)\end{array}$ & $\begin{array}{c}2.226^{\circ} \\
\pm 0.844(2)\end{array}$ & $\begin{array}{c}1.936^{\circ} \\
\pm 0.626(4)\end{array}$ \\
\hline$\alpha$-ketoglutarate & $\begin{array}{c}0.178^{\circ} \\
\pm 0.066(8)\end{array}$ & $\begin{array}{c}0.099 \\
\pm 0.057(6)\end{array}$ & $\begin{array}{c}0.069 \\
\pm 0.033(14)\end{array}$ & $\begin{array}{c}0.100 \\
\pm 0.075(7)\end{array}$ & $\begin{array}{c}0.057 \\
\pm 0.009(3)\end{array}$ & $\begin{array}{c}0.127 \\
\pm 0.098(2)\end{array}$ & $\begin{array}{c}0.020^{\circ} \\
\pm 0.001(2)\end{array}$ & $\begin{array}{c}0.028 \\
\pm 0.016(2)\end{array}$ & $\begin{array}{c}0.037 \\
\pm 0.024(3)\end{array}$ \\
\hline $\begin{array}{l}\text { Glycerol-3- } \\
\text { phosphate }\end{array}$ & $\begin{array}{c}0.423 \\
\pm 0.238(8)\end{array}$ & $\begin{array}{c}0.673^{\circ} \\
\pm 0.275(6)\end{array}$ & $\begin{array}{c}0.598^{*} \\
\pm 0.304(13)\end{array}$ & $\begin{aligned} & 0.218 \\
\pm & 0.182(6)\end{aligned}$ & $\begin{array}{c}0.238^{*} \\
\pm 0.137(4)\end{array}$ & $\begin{array}{c}0.429 \\
\pm 0.223(2)\end{array}$ & $\begin{array}{c}0.623 \\
\pm 0.522(3)\end{array}$ & nd & $\begin{array}{c}0.321 \\
\pm 0.274(4)\end{array}$ \\
\hline $\mathrm{NH}_{4}{ }^{*}$ & $\begin{array}{c}1.179 \\
\pm 0.465(8)\end{array}$ & $\begin{array}{c}0.862 \\
\pm 0.387(6)\end{array}$ & $\begin{array}{c}1.873^{\circ} \\
\pm 0.859(15)\end{array}$ & $\begin{array}{c}1.099 \\
\pm 0.424(7)\end{array}$ & $\begin{array}{c}1.898 \\
\pm 0.811(4)\end{array}$ & $\begin{array}{c}0.591 \\
\pm 0.256(2)\end{array}$ & $\begin{array}{c}1.761 \\
\pm 0.865(3)\end{array}$ & $\begin{array}{c}1.620 \\
\pm 0.162(2)\end{array}$ & $\begin{array}{c}1.423 \\
\pm 0.604(4)\end{array}$ \\
\hline \multicolumn{10}{|l|}{ Blood } \\
\hline G1P & $\begin{array}{c}0.306 \\
\pm 0.061(5)\end{array}$ & $\begin{array}{c}0.331 \\
\pm 0.149(6)\end{array}$ & $\begin{array}{c}0.422 \\
\pm 0.319(13)\end{array}$ & $\begin{array}{c}0.218 \\
\pm 0.077(8)\end{array}$ & $\begin{array}{c}0.362 \\
\pm 0.291(4)\end{array}$ & $0.400(1)$ & $\begin{array}{c}0.466^{\circ} \\
\pm 0.115(2)\end{array}$ & $\begin{array}{c}0.202 \\
\pm 0.145(2)\end{array}$ & $\begin{array}{c}0.302 \\
\pm 0.036(2)\end{array}$ \\
\hline G6P & $\begin{array}{r}0.802 * \\
\pm 0.405(7)\end{array}$ & $\begin{array}{c}0.932 * \\
\pm 0.360(6)\end{array}$ & $\begin{array}{c}0.582 * \\
\pm 0.204(16)\end{array}$ & $\begin{array}{c}0.372 \\
\pm 0.135(12)\end{array}$ & $\begin{array}{c}0.614 \\
\pm 0.658(4)\end{array}$ & $\begin{array}{c}0.555 \\
\pm 0.505(2)\end{array}$ & $\begin{array}{c}0.504^{\circ} \\
\pm 0.034 \text { (3) }\end{array}$ & $\begin{array}{c}0.427 \\
\pm 0.082(2)\end{array}$ & $\begin{array}{r}0.851 * \\
\pm 0.291 \text { (4) }\end{array}$ \\
\hline
\end{tabular}

glycerol-3-phosphate concentrations in liver, lactate levels in blood and blood dry mass, as well as G1P concentration in muscle (Figs. 1, 2 \& 5, Tables 1 \& 2).

Table 3. Solea solea. Calculated total anaerobic energy production expressed in $\mu \mathrm{mol}$ ATP $\mathrm{h}^{-1}$ for a standard fish weighing $100 \mathrm{~g}$, compared to aerobic standard metabolic rate (SMR) and aerobic voluntarily active metabolic rate (AMR). The absolute capacity for total anaerobic ATP production is given in the second column

\begin{tabular}{|c|c|c|}
\hline Treatment & $\begin{array}{l}\mu \mathrm{mol} \text { ATP } \\
100 \mathrm{~g}^{-1} \mathrm{~h}^{-1}\end{array}$ & $\begin{array}{c}\mu \mathrm{mol} \text { ATP } \\
100 \mathrm{~g}^{-1} \text { exposure }^{-1}\end{array}$ \\
\hline Hypoxia $12 \%$ & $52.1 \pm 36.8$ & 625.2 \\
\hline Hypoxia $6 \%$ & $149.9 \pm 56.3$ & 1798.8 \\
\hline Anoxia & $1776.9 \pm 649.2$ & 3074.0 \\
\hline Exhaustion & $6833.9 \pm 2172.5$ & 3132.2 \\
\hline Aerobic SMR ${ }^{\mathrm{a}}$ & 817 & \\
\hline Aerobic AMR $^{a}$ & 2852 & \\
\hline \multicolumn{3}{|c|}{$\begin{array}{l}{ }^{2} \text { Calculated from oxygen consumption rates at normoxi } \\
\text { SMR and AMR: } 4.36 \text { and } 15.22 \mathrm{mg} \mathrm{O}_{2} 100 \mathrm{~g}^{-1} \mathrm{~h}^{-1} \text {, respec } \\
\text { tively (Van den Thillart et al. } 1994 \text { ) }\end{array}$} \\
\hline
\end{tabular}

\section{Forced exercise and recovery}

The factorial aerobic scope for activity, defined as AMR/SMR, in sole is 3.5 (Table 3; Van den Thillart et al. 1994, p. 128) and lies within the expected range of 3 to 7 for fishes (Jobling 1994, p. 128). Forced exercise caused the highest rate of anaerobic energy production, reaching 8 times the aerobic SMR (Table 3). In sedentary flatfish routine metabolic rate is 30 to $40 \%$ lower than in roundfish like cyprinids or salmonids (Wood et al. 1979, Duthie 1982). This becomes evident by comparing the weight-corrected routine metabolic rates at $20^{\circ} \mathrm{C}$ of sole $\left(7.86 \mathrm{mg} \mathrm{O}_{2} 100 \mathrm{~g}^{-1} \mathrm{~h}^{-1}\right.$; Van den Thillart et al. 1994) with that of cyprinids (15.24 $\mathrm{mg} \mathrm{O}_{2}$ $100 \mathrm{~g}^{-1} \mathrm{~h}^{-1}$; Wieser 1991) and salmonids (15 to $45 \mathrm{mg} \mathrm{O}_{2}$ $100 \mathrm{~g}^{-1} \mathrm{~h}^{-1}$; Brett 1972, Wood et al. 1979). Therefore, lower lactate clearance rates and longer recovery periods may be expected for flatfish than for roundfish.

The lactate clearance rate of Solea solea can be estimated from oxygen consumption and mean lactate concentration accumulated after exhaustion. The oxygen consumption of sole is 136.3 and $475.6 \mu \mathrm{mol} \mathrm{O}_{2}$ 
$100 \mathrm{~g}^{-1} \mathrm{~h}^{-1}$ at SMR and active metabolic rate (AMR). respectively (Van den Thillart et al. 1994). Since the oxygen:lactate molar ratio at complete oxidation is 3 , maximal lactate clearance rate by oxidation will be between 45.4 and $158.5 \mu$ mol lactate $100 \mathrm{~g}^{-1} \mathrm{~h}^{-1}$. Considering only the lactate concentration of $17 \mu \mathrm{mol} \mathrm{g}^{-1}$ fresh weight in muscle ( $65 \%$ of body weight) after $104 \mathrm{~min}$ of anoxic exposure or $27 \mathrm{~min}$ of forced exercise (Fig. 1), it would take about $7 \mathrm{~h}$ at AMR or $24 \mathrm{~h}$ at SMR for muscle lactate concentration to return to normoxic and resting levels. The immobility of sole observed after forced exercise makes a recovery time of $24 \mathrm{~h}$ more probable. Similar values were predicted by Milligan \& McDonald (1988) for starry flounder at 9 to $11^{\circ} \mathrm{C}$, in which the predicted as well as the observed lactate clearance time was found to be larger in flatfish than in salmonids (Milligan \& Wood 1986, Milligan \& Wood 1987a, Milligan \& McDonald 1988). Cyprinids recover from exhaustion within 2 to $4 \mathrm{~h}$ at $20^{\circ} \mathrm{C}$, and within $8 \mathrm{~h}$ at $4^{\circ} \mathrm{C}$ (Lackner et al. 1988, Dalla Via et al. 1989).

Our measurements cover the first $4 \mathrm{~h}$ of recovery. Muscle ATP and the depleted phosphoscreatine-pool regain control levels after 0.5 and $4 \mathrm{~h}$ respectively. Lactate remained significantly increased, and the high concentrations of glucose, G6P, G1P, F6P, fructose, and glycerol-3-phosphate after $4 \mathrm{~h}$ of recovery indicate gluconeogenesis and the beginning of glycogen synthesis in muscle. Pyruvate, malate, $\alpha$-ketoglutarate, and glycerol-3-phosphate remained elevated in muscle $4 \mathrm{~h}$ postexercise, indicating an impairment of mitochondrial metabolism. Liver lactate increased more than 3 -fold during the first $4 \mathrm{~h}$ of recovery, suggesting an uptake of blood lactate rather than glycogenolysis since glucose, G6P, and G1P concentrations had already returned to control levels after the first hour of recovery. Significantly higher G6P and lower ATP levels in blood may indicate the shift to increased hemoglobin-oxygen affinity as discussed for severe hypoxia. A constant and high level of hyperglycaemia suggests stress-induced endocrine mechanisms.

\section{The flatfish paradox of lactate distribution}

'Blood lactate levels never reach those seen in the white muscle' (Jobling 1994, p. 131). However, under hypoxia sole show a 1.4- and 2-fold higher lactate level in blood than in muscle at 12 and $6 \%$ air saturation, respectively (Fig. 1). Is this an exception to an otherwise general rule?

In the case of Solea solea we have to consider that the fish were exposed to $12 \mathrm{~h}$ of severe hypoxia, and that the glycolytic flux might have changed during exposure time, from high in the beginning to low at the end. It has been suggested that most vertebrates are intolerant to hypoxia/anoxia because they are unable to rapidly increase their glycolytic rate of ATP production for immediate needs in order to benefit from metabolic depression as a long-term accomodation (Nilsson \& Lutz 1993). Therefore, a 2 -step response may be expected, a first emergency one with high glycolytic ATP production, and a second long-term accomodation reducing the rate of ATP consumption (metabolic depression). In fact, overall metabolic depression during hypoxic exposure has been found in sole (Dalla Via et al. 1994), although this species is also capable of high rates of anaerobic ATP production (see Table 3).

Low glycolytic flux at the end of hypoxic exposure is indicated by low anaerobic energy production (Table 3), and stable [ATP] in muscle (Fig. 3). In consequence a high energy charge may be expected which down regulates the PFK activity and consequently reduces the glycolytic flux. With glycogenolysis still progressing a reduction of glycolytic flux should lead to an increase of G1P and G6P levels, which was indeed found to be the case in muscle (Table 1). Under hypoxia, phosphocreatine decreased by only $45 \%$, whereas after exhaustive exercise and anoxia phosphocreatine fell to $5.5 \%$ and $12.7 \%$ of control levels, respectively (Fig. 4). F6P increased in muscle because it is in equilibrium with G6P (Table 1). Pyruvate may already have been flowing into the mitochondria since increases were only up to 2 -fold control concentrations, compared to the 15 -fold increase under exhaustive exercise (Table 1). An increase in malate, indicating insufficient capacity of the tricarboxylic cycle (Dalla Via et al. 1989), was significant only at $6 \%$ air saturation, whereas under anoxia and exhaustive exercise malate concentration was up to 3 times the control values.

Lactic acid is produced in all tissues, mainly in active tissues like white muscle, but it is not known how fast and under what conditions lactate is released into the circulation. More than $80 \%$ of the lactate produced in fish muscle is retained and metabolised in situ, the remainder being released (Milligan \& Girard 1993). Wardle (1978) considered increased catecholamine levels to be responsible for lactate retention in muscle cells of flatfish. Plasma catecholamines rise during environmental hypoxia below $30 \%$ air saturation in rainbow trout, dogfish, and Atlantic cod (see review in Randall \& Perry 1992: p. 264), but the circulating catecholamine levels depend on the intensity of the hypoxic level itself, how rapidly the final water $P_{\mathrm{O}_{2}}$ is attained, and how long hypoxic exposure persists. In addition, noradrenaline and adrenaline may change differently due to a fall of $P_{\mathrm{O}_{2}}$ (Randall \& Perry 1992). The picture presented in the literature is further blurred by seasonal differences in catecholamine release (Thomas et al. 1991) and by species differences 
in absolute levels of catecholamines (Randall \& Perry 1992).

Since in our hypoxia experiments with Solea solea the final water $P_{\mathrm{O}_{2}}$ level was attained slowly the rate of change may not have been sufficient to invoke catecholamine release. Even if sole had experienced high initial catecholamine levels, concentrations would have been lowered within the $12 \mathrm{~h}$ of exposure due to the short biological halftime of these hormones (less than $10 \mathrm{~min}$; Nekvasil \& Olson 1986). According to Wardle (1978) a low catecholamine stimulus would lead to 'non-retainment' of lactate in muscle cells, explaining the high blood lactate levels found in sole under hypoxia (Fig. 1). Exhaustive exercise for 10 to $30 \mathrm{~min}$ induces a high catecholamine release (Milligan \& Wood 1987b, Wood 1991) leading to a 'retainment' of lactate in muscle tissue (Wardle 1978). This is also indicated by the low blood lactate level in sole under exhaustive exercise (Fig. 1).

High blood lactate levels under hypoxia (up to $15 \mu \mathrm{mol} \mathrm{\textrm {g } ^ { - 1 }}$ blood) were also found in the flounder Platichthys flesus (Jørgensen \& Mustafa 1980). At exposures of up to $55 \mathrm{~h}$ blood lactate decreased continuously, this leading to an inversion of the muscle:blood ratio for lactate and corroborating our findings in sole.

\section{The concept of lactate 'releasers' and 'non-releasers'}

The origin and metabolic fate of lactate in fish has been under discussion for a long time. Anaerobic metabolism, induced by functional or environmental hypoxia/anoxia, results in a depletion of energy stores (phosphocreatine, ATP, glycogen) and accumulation of lactate. The classic Cori cycle is of minor importance in fish. Only $2 \%$ of the lactate clearance following exercise is due to hepatic gluconeogenesis, less than $1 \%$ of the blood glucose contributes to muscle glycogen restoration (Pagnotta \& Milligan 1991), and more than $80 \%$ of the lactate generated by the exercised muscle is retained in the muscle mass (Milligan \& Wood 1986, Milligan \& Wood 1987a, Milligan \& Girard 1993).

Species differences have been observed for lactate release from muscle to blood after exhaustive exercise: sluggish benthic fishes, like flatfish, release less than $1 \%$ of the total lactate produced in the muscle, whereas more active fish species, like salmonids, release between 10 and $20 \%$ of the total lactate produced into the blood space (Milligan \& Girard 1993). The first group is characterized by blood lactate concentrations rarely exceeding 1 to $2 \mathrm{mmol} \mathrm{l}^{-1}$ and by 10 - to 15 -fold higher muscle lactate concentrations, whereas in the second group blood lactate concentrations of 15 to $20 \mathrm{mmoll}^{-1}$ and twice as high muscle concentrations were found (Milligan \& Girard 1993).
These differences led to the division of fish species into lactate 'releasers' and 'non-releasers' after exhaustive exercise.

The common sole Solea solea, as a typical representative of benthic flatfish, would be expected to belong to the group of 'non-releasers'. Unexpectedly high blood lactate levels found in sole after hypoxic exposure necessitate a change in definition. Under severe hypoxia the sole performs as a 'lactate releaser', reaching, after $12 \mathrm{~h}$ of exposure, blood lactate levels of up to $19.8 \mu \mathrm{mol} \mathrm{ml}{ }^{-1}$ and $9.6 \mu \mathrm{mol} \mathrm{g}{ }^{-1}$ in muscle. Under anoxia and exhaustive exercise lactate concentrations reflect conditions of a lactate 'non-releaser', attaining 7.6 and $3.9 \mu \mathrm{mol} \mathrm{ml}^{-1}$ lactate in blood and 17.4 and 17.9 $\mu \mathrm{mol} \mathrm{g} \mathrm{g}^{-1}$ lactate in muscle, under anoxia and exhaustive exercise, respectively (Fig. 1). Even if the blood lactate values of 3.9 and $7.6 \mu \mathrm{mol} \mathrm{ml}^{-1}$ are not below the postulated threshold of $2 \mu \mathrm{mol} \mathrm{ml}^{-1}$, an inversion of the ratio muscle:blood lactate among treatments is evident: hypoxia, muscle:blood $=0.5$; anoxia, 2.3 ; exhaustive exercise, 4.6. This sequence is also positively correlated with the rate of total anaerobic energy production (Table 3 ). The more severe the anoxic load, the higher the rate of anaerobic ATP production and the more pronounced the lactate retention in the muscle.

The concept of lactate 'releasers' and 'non-releasers' is mainly based on the polarity of pleuronectid and salmonid species, the first qualifying as 'nonreleasers', the latter as 'releasers'. Other species, like the sea lamprey Petromyzon marinus and the Atlantic cod Gadus morhua, show an intermediate pattern after exhaustive exercise, with blood lactate concentrations of 5.6 and $7.9 \mu \mathrm{mol} \mathrm{ml}^{-1}$, respectively (Beamish 1968 , Tufts 1991). Furthermore, body size has an important influence on the metabolic status of fish before and after exercise. Goolish (1989) found a size-dependent increase in lactate production in the white muscle of rainbow trout after exhaustive exercise, with lactate concentration reaching almost twice the amount in larger fish than in smaller ones. As shown by Reidy et al. (1995), post-exercise metabolic rate depends significantly upon how exhaustion was induced. The increased blood lactate concentration of $3.9 \mu \mathrm{mol} \mathrm{ml}^{-1}$ in sole after exhaustive exercise, slightly higher than expected for a lactate 'non-releaser', may be due to chasing the fish around for almost half an hour until exhaustion, while in other experiments stress conditions lasted only for 5 to $10 \mathrm{~min}$ (Kieffer et al. 1994). Temperature is another factor which may interfere severely with the concept of lactate 'releaser' and 'nonreleaser'. Lactate accumulation in fish is influenced by temperature, at least in cyprinids (Wieser et al. 1986, Dalla Via et al. 1989), whereas it seems not to be affected in rainbow trout white muscle (Kieffer et al. 
1994). A closer look at blood lactate values in rainbow trout reveals a significant relation between temperature and blood lactate concentration. At high temperatures trout show a 'releaser's' lactate concentration $\left(18^{\circ} \mathrm{C}\right.$ : $12.6 \mu \mathrm{mol} \mathrm{ml} \mathrm{m}^{-1}$ blood; $15^{\circ} \mathrm{C}: 19.7 \mu \mathrm{mol} \mathrm{m} \mathrm{m}^{-1}$ blood), whereas at low temperatures 'non-releaser's' values are approximated $\left(5^{\circ} \mathrm{C}\right.$ : $4.0 \mu \mathrm{mol} \mathrm{m} \mathrm{ml}^{-1}$ blood) (Milligan \& Wood 1986, Kieffer et al, 1994).

\section{Perspectives}

In one and the same species (Solea solea), at identical temperature and acclimation conditions, we found 3 different metabolic patterns for 3 differently induced stress situations: the pattern of a lactate 'releaser' under hypoxia, an intermediary situation under anoxia, and the pattern of a 'non-releaser' under exhaustive exercise. The conclusion seems inevitable that the concept of lactate 'releaser' and 'non-releaser' cannot be applied on a species basis alone but must take into account the type and intensity of the induced stress situation.

Acknowledgements. We thank G. Vitali for assistance and maintenance of captured animals, and $\mathrm{Ch}$. Lederer for valuable assistance during part of the biochemical analysis. Suggestions and critical reading by W. Wieser improved the manuscript. Our thanks are extended to the Centro di Ricerche Marine at Cesenatico (Italy) for allowing us to use their facilities during part of this investigation. Funding was provided by the Commission of the European Communities 4th Environment R\&D programme under contract \#EV4V-0122-NL. The generous support by the 'Österreichische Forschungsgemeinschaft' (Vienna, Austria) to J.D.V. is gratefully acknowledged (Project 09/0021).

\section{LITERATURE CITED}

Beamish FWH (1968) Glycogen and lactic acid concentrations in Atlantic cod, Gadus morhua, in relation to exercise. $J$ Fish Res Bd Can 25:837-851

Bergmeyer HU (ed) (1984) Methods of enzymatic analysis, Vol VI. Metabolites 1: Carbohydrates. Verlag Chemie, Weinheim

Bergmeyer HU (ed) (1985a) Methods of enzymatic analysis, Vol VII. Metabolites 2: Tri- and Dicarboxylic acids, purines, pyrimidines and derivatives, coenzymes, inorganic compounds. Verlag Chemie, Weinheim

Bergmeyer HU (ed) (1985b) Methods of enzymatic analysis, Vol VIII. Metabolites 3: Lipids, amino acids and related compounds. Verlag Chemie, Weinheim

Brett JR (1972) The metabolic demand for oxygen in fish, particularly salmonids, and a comparison with other vertebrates. Respir Physiol 14:151-170

Dalla Via GJ, Huber M, Wieser W, Lackner R (1989) Temperature related responses of intermediary metabolism to forced exercise and recovery in juvenile Rutilus rutilus (L.) (Cyprinidae: Teleostei). Physiol Zool 62:964-976

Dalla Via GJ, Lackner R (1991) Metaboliten des Intermediärstoffwechsels: Verbesserte Probenaufbereitung mittels einer Mörsermühle. Veröff Univ Innsbruck 181: 93-99

Dalla Via J, Van den Thillart G, Cattani O, De Zwaan A (1994) Influence of long-term hypoxia exposure on the energy metabolism of Solea solea. II. Intermediary metabolism in blood, liver and muscle. Mar Ecol Prog Ser 111:17-27

Duthie GG (1982) The respiratory metabolism of temperature-adapted flatfish at rest and during swimming activity and the use of anaerobic metabolism at moderate swimming speeds. J Exp Biol 97:359-373

Girard SS, Milligan CL (1992) The metabolic fate of bloodborne lactate in winter flounder (Pseudopleuronectes americanus) during recovery from strenuous exercise. Physiol Zool 65:1114-1134

Goolish EM (1989) The scaling of aerobic and anaerobic muscle power in rainbow trout (Salmo gairdneri). J Exp Biol $147: 493-505$

Herndl GJ, Bochdansky AB, Kaltenböck E, Müller-Niklas G (1993) Marine snow in the Northern Adriatic Sea: major role of microbes in the metabolism of marine snow. Biologia Marina SIBM 1:1-12

Jobling M (1994) Fish bioenergetics. Chapman and Hall, London

Jørgensen JB, Mustafa T (1980) The effect of hypoxia on carbohydrate metabolism in flounder (Platichthys flesus L.) 1. Utilization of glycogen and accumulation of glycolytic end product in various tissues. Comp Biochem Physiol 67B: $243-248$

Kieffer JD, Currie S, Tufts BL (1994) Effects of environmental temperature on the metabolic and acid-base responses of rainbow trout to exhaustive exercise. J Exp Biol 194: 299-317

Lackner R, Wieser W, Huber M, Dalla Via J (1988) Responses of intermediary metabolism to acute handling stress and recovery in untrained and trained Leuciscus cephalus (Cyprinidae, Teleostei). J Exp Biol 140:393-404

Lagardère JP, Ducamp JJ, Frikha L, Sperandio M (1988) Ultrasonic tracking of common sole juveniles (Solea vulgaris Quensel, 1806) in a saltmarsh: methods and fish response to some environmental factors. J Appl Ichthyol 4: $87-96$

Milligan CL, Farrell AP (1986) Extracellular and intracellular acid-base status following strenuous activity in the sea raven (Hemitripterus americanus). J Comp Physiol B 156: $583-590$

Milligan CL. Girard SS (1993) Lactate metabolism in rainbow trout. J Exp Biol 180:175-193

Milligan CL, McDonald DG (1988) In vivo lactate kinetics at rest and during recovery from exhaustive exercise in coho salmon (Oncorhynchus kisutch) and starry flounder (Platichthys stellatus). J Exp Biol 135:119-131

Milligan CL, Wood CM (1986) Tissue intracellular acid-base status and the fate of lactate after exhaustive exercise in the rainbow trout. J Exp Biol 123:123-144

Milligan CL, Wood CM (1987a) Muscle and liver intracellular acid-base and metabolite status after strenuous activity in the inactive, benthic starry flounder Platichthys stellatus. Physiol Zool 60(1):54-68

Milligan CL, Wood CM (1987b) Regulation of blood oxygen transport and red cell $\mathrm{pH}_{4}$ after exhaustive activity in rainbow trout (Salmo gairdneri) and starry flounder (Platichthys stellatus). J Exp Biol 133:263-382

Nekvasil NP, Olson KR (1986) Plasma clearance, metabolism, and tissue accumulation of ${ }^{3} \mathrm{H}$-labelled catecholamines in trout. Am J Physiol 259:R519-R525

Nikinmaa M (1986) Control of red cell pH in teleost fish. Ann Zool Fennici 23:223-235 
Nilsson GE, Lutz PL (1993) Role of GABA in hypoxia tolerance, metabolic depression and hibernation-possible links to neurotransmitter evolution. Comp Biochem Physiol 105C:329-336

Pagnotta A, Milligan CL (1991) The role of blood glucose in the restoration of muscle glycogen during recovery from exhaustive exercise in rainbow trout (Oncorhynchus mykiss) and winter flounder (Pseudopleuronectes americanus). J Exp Biol 161:489-508

Randall DJ, Perry SF (1992) Catecholamines. In: Hoar WS, Randall DJ, Farrell AP (eds) Fish physiology, Vol 12B. Academic Press, London, p 255-299

Reidy SP, Nelson JA, Tang Y, Kerr SR (1995) Post-exercise metabolic rate in Atlantic cod and its dependence upon the method of exhaustion. J Fish Biol 47:377-386

Rinaldi A, Montanari G, Ghetti A, Ferrari CR (1993) Anossie nelle acque costiere dell'Adriatico nord-occidentale. Loro evoluzione e conseguenze sull'ecosistema bentonico. Biologia Marina SIBM 1:79-89

Thomas S, Kinkead R, Wood CM, Walsh PJ, Perry SF (1991) Desensitization of adrenaline-induced red blood cell $\mathrm{H}^{*}$ extrusion in vitro after chronic exposure of rainbow trout (Salmo gairdneri) to moderate environmental hypoxia. J Exp Biol 156:233-248

Tufts BL (1991) Acid-base regulation and blood gas transport following exhaustive exercise in an agnathan, the sea lamprey Petromyzon marinus. J Exp Biol 159:371-385

Turner JD, Wood CM, Höbe H (1983) Physiological consequences of severe exercise in the inactive benthic flathead

This article was submitted to the editor sole (Hippoglossoides elassodon): a comparison with the active pelagic rainbow trout (Salmo gairdneri). J Exp Biol 104:269-288

Van den Thillart G, Dalla Via J (1993) Influence of long-term hypoxia exposure on aerobic and anaerobic metabolism of Solea solea. Biologia Marina SIBM 1:103-108

Van den Thillart G, Dalla Via J, Vitali G, Cortesi P (1994) Influence of long-term hypoxia exposure on the energy metabolism of Solea solea: I. Critical oxygen levels for aerobic and anaerobic metabolism. Mar Ecol Prog Ser 104 109-117

Wardle CS (1978) Non-release of lactic acid from anaerobic swimming muscle of plaice Pleuronectes platessa L.: a stress reaction. J Exp Biol 77:141-155

Wieser W (1991) Physiological energetics and ecophysiology. In: Winfield IJ, Nelson JS (eds) Cyprinid fishes. Systematics, biology and exploitation. Chapman and Hall, London. p 426-455

Wieser W, Koch F, Drexel E, Platzer U (1986) 'Stress' reactions in teleosts: effects of temperature and activity on anaerobic energy production in roach (Rutilus rutilus L.). Comp Biochem Physiol 83A:41-45

Wood CM (1991) Acid-base and ion balance, metabolism, and their interactions, after exhaustive exercise in fish. J Exp Biol 160:285-308

Wood CM, McMahon BR, McDonald DG (1979) Respiratory gas exchange in the resting starry flounder, Platichthys stellatus: a comparison with other teleosts. J Exp Biol 78: $167-179$

Manuscript received: June 11, 1997

Accepted: July 1, 1997 